Article

\title{
Loading Capacity of Sewage Sludge for Forestry Application in Chinese Provincial Capital Cities
}

\author{
Xiaoxia Zhang ${ }^{1,2}$, Tonggang Zha ${ }^{1, *}$, Jiangang Zhu ${ }^{3}$, Xiaoping Guo ${ }^{1}$ and Yi Liu ${ }^{1}$ \\ 1 School of Soil and Water Conservation, Beijing Forestry University, Beijing 100083, China; \\ Zhangxx0708@bjfu.edu.cn (X.Z.); guoxp@bjfu.edu.cn (X.G.); zhs418473740@bjfu.edu.cn (Y.L.) \\ 2 The Third Construction Co., Ltd. of China Construction First Group, Beijing 100161, China \\ 3 Beijing Forestry Carbon Administration, Beijing 100013, China; zhujg@bfdic.com \\ * Correspondence: zhtg73@bjfu.edu.cn
}

Received: 6 August 2020; Accepted: 9 September 2020; Published: 14 September 2020

check for updates

\begin{abstract}
The application of sewage sludge (SS) in forestry is considered a viable option. However, the long-term application of SS potentially leads to metal accumulation, posing an environmental risk. Understanding the loading capacity of SS for forestry application is therefore of great significance. We used data from published studies and statistical bulletins across 31 provincial capital cities (PCCs) in China to calculate the loading capacity (LC) of SS for forestry application for each PCC. The results are as follows: (1) the mean value of the priority control threshold was $33 \mathrm{t} \cdot \mathrm{ha}^{-1} \cdot \mathrm{y}^{-1}$ in 31 PCCs, while the variations ranged from 7 to $91 \mathrm{t} \cdot \mathrm{ha}^{-1} \cdot \mathrm{y}^{-1}$ among different PCCs. The priority control thresholds $\left(S_{\min } \mathrm{s}\right)$ of $1 / 2$ PCCs were higher than $30 \mathrm{t} \cdot \mathrm{ha}^{-1} \cdot \mathrm{y}^{-1}(\mathrm{CJ}-\mathrm{T} 362-2011)$. The $S_{\text {min }}$ values of Lanzhou, Tianjin, Hohhot, Shanghai, and Yinchuan were above $55 \mathrm{t} \cdot \mathrm{ha}^{-1} \cdot \mathrm{y}^{-1}$, but $S_{\text {min }}$ values of Kunming and Changsha were below $10 \mathrm{t} \cdot \mathrm{ha}^{-1} \cdot \mathrm{y}^{-1}$. (2) Cd was the priority control metal in most of the PCCs (27/31), with the exception of Shanghai and Guangzhou (Cu), Beijing $(\mathrm{Hg})$, and Tianjin $(\mathrm{Zn})$. (3) The total loading capacity was 507 million $\mathrm{t} \cdot \mathrm{y}^{-1}$, which was 125 times higher than the total quantity of the dry SS $\left(404 \times 10^{4} \mathrm{t}\right)$ for the 31 PCCs. Our results have important practical significance for the use of urban sludge forest land in China and suggest that SS disposal policies need to be tailored to specific regions. We provide a scientific basis to guide the development of national and provincial forestry policies.
\end{abstract}

Keywords: sewage sludge; forestry application; loading capacity; priority control metal

\section{Introduction}

Sewage sludge (SS) is a residue of domestic and industrial wastewater treatment [1-3], and global sewage production exceeded 300 billion $\mathrm{t} \cdot \mathrm{y}^{-1}$ in 2010 [4,5]. Although improvements in urban sewage treatment capacity have resulted in enhanced water quality, the amount of sewage sludge has significantly increased. By the end of 2017, the capacity of sewage treatment plants in China was 157 million $t \cdot d^{-1}$, with municipal domestic sewage treatment accounting for 42.6 billion $\mathrm{m}^{3}$; the amount of dry sludge produced was 9.51 million $t$ [6]. The disposal and treatment of SS are major challenges in sewage management [1], and sustainable sludge handling needs to meet the requirements of efficient resource recycling without the distribution of harmful substances.

Sewage sludge contains large amounts of organic carbon as well as nitrogen, phosphorus, potassium, and various trace elements necessary for plant growth, fertility, thereby potentially improving soil structure and increasing plant growth [7-10]. Municipal sewage sludge, given that it meets the quality criteria for agricultural use, stimulates crop yield [11]. In a previous study, in the underlying soil horizons after the application of $3 \mathrm{t} \mathrm{ha}^{-1} \cdot \mathrm{y}^{-1}$ of SS, the trace metal contents remained stable [12]. The application of sludge at a rate of $3 \mathrm{t} \mathrm{ha}^{-1} \cdot \mathrm{y}^{-1}$ did not significantly increase 
the bioavailability of $\mathrm{As}, \mathrm{Cu}, \mathrm{Zn}, \mathrm{Hg}, \mathrm{Pb}, \mathrm{Cd}$, and $\mathrm{Cr}$, as demonstrated for mushroom cultivation [13]. In another study, dried urban sewage sludge residues were applied to a sugar maple (Acer saccharum Marsh.) and yellow birch (Betula alleghaniensis Britton) forest in Quebec at a dose of $38.63 \mathrm{tha}{ }^{-1} \cdot \mathrm{y}^{-1}$, and $\mathrm{Zn}, \mathrm{Cd}, \mathrm{Cu}$, and $\mathrm{Pb}$ concentrations were below the detection limits [14]. These studies have shown that the leaching of major and trace elements into the soil is generally low at low SS quantities [11-14], most likely because a high percentage of elements may be retained in the humus layer by metal complexation to the surface of organic matter [15-18]. In a study in Sweden, long-term application of sewage sludge to farmland did not result in significant changes in the soil bacterial resistome [19]. However, such an approach can result in the accumulation of metals, potentially entering the food chain and threatening human health $[20,21]$. Farmers are generally not inclined to use SS because of its negative reputation and unpleasant odors [22]. However, given the fact that most wastewater treatment plants are in cities and that transportation is expensive, the application in forests (zero or minimal transportation cost) may represent a viable alternative of sludge disposal in China, which also would avoid direct contact with animals and humans $[23,24]$. So far, sewage sludge has been mainly applied to forest surfaces, while sludge compost has been used as a tree seedling container media [17], mainly for tree species such as poplar, paulownia, Chinese pine, black locust, Chinese pagoda tree, and Chinese arborvitae [25]. Based on a previous study, SS in Shenyang is suitable for application to forests and grasslands or nurseries, where food chain contamination with cadmium is not a concern [26]. A study on the influences of sewage sludge on the degradation of hexazinone and the formation of its major metabolites has improved our understanding of the pollution risk when applying SS to forest soil [27]. Sewage sludge-based Bacillus thuringiensis production, followed by its use in forest and agro-crops for pest control, is an acceptable disposal practice [28].

When evaluating the applicability of SS, metal concentrations are still an important index [1]. According to the Soil Pollution Survey of China in 2014, metal concentrations in forests exceeded the standard levels by $10 \%$, with $\mathrm{Cd}$ and As being the main contaminants [29]. The metals $\mathrm{Zn}, \mathrm{Cu}$, and $\mathrm{Ni}$ are considered the main metals limiting the application of SS in England [30], and in a study on grasslands which had received sludge for more than 10 years at a dose of $39 \mathrm{t} \cdot \mathrm{ha}^{-1} \cdot \mathrm{y}^{-1}$, the soil concentrations of $\mathrm{Hg}$ and $\mathrm{Cd}$ were significantly increased [31]. With the development of efficient transportation and heating techniques, $\mathrm{Cd}$ and $\mathrm{Hg}$ are the elements most likely limiting the application of SS because of their inertness, migration, high biomagnification, and strong toxicity [32-34]. In an earlier study, the application of $6 \mathrm{t} \cdot \mathrm{ha}^{-1} \cdot \mathrm{y}^{-1}$ of SS with low trace element concentrations modified the transfer of $\mathrm{Cd}, \mathrm{Hg}$, and $\mathrm{Pb}$ to mushrooms in some sites [18].

In 2000, China started to make efforts to decrease its metal emissions by the implementation of stricter regulations [1]. In this sense, understanding the loading capacity of SS for forestry application is of great significance in terms of resource reuse [35,36]. In China, the threshold level of SS used in forests is $30 \mathrm{t} \cdot \mathrm{ha}^{-1} \cdot \mathrm{y}^{-1}$, and continuous application should not exceed 15 years according to the Standard CJ/T 362-2011 [37]. Nevertheless, the natural conditions and the area of urbanization in China differ largely. The lack of specific thresholds restricts the application of SS in forestry, making it necessary to establish threshold values for each city, based on the concentrations of metals in SS, as well as the soil dynamic environmental capacity [38]. In this context, the objectives of this study were to (1) screen and identify the priority control metal of SS for forestry application and to (2) determine and design its maximum loading capacities, with the overall aim to propose suggestions for each provincial capital city (PCC). This will be helpful to determine the potential of urban sludge for forestry application, eventually providing a theoretical basis for national and provincial forestry policies.

\section{Methods}

\subsection{Data Preparation}

We analyzed the metal concentrations in SS in 31 PCCs in mainland China, using the bibliometric method to screen 1082 valid data from 129 references (Figure 1) from international studies published 
between 2006 and 2018, including the Chinese National Knowledge Infrastructure, the Science Direct database, and some official reports (see Tables S1 and S2). The data screening principles were as follows: first, the metal testing protocols of the selected studies were associated with strict quality assurance and control, containing parallel samples, blank samples, and standard materials, and the recovery rate needed to be conformed to the determination standard. Second, in case the data were normally distributed, the average metal content was represented using the arithmetic mean; if the data conformed to a logarithmic normal distribution, the geometric average was used. Data on the baseline values of soil metals were obtained from our previous research [29]; area of forestry and quantity of dry SS treated data were obtained from the Statistical Yearbook on Urban Construction 2017 [39]. Spatial distribution maps were produced with the GIS software ArcGIS 10.

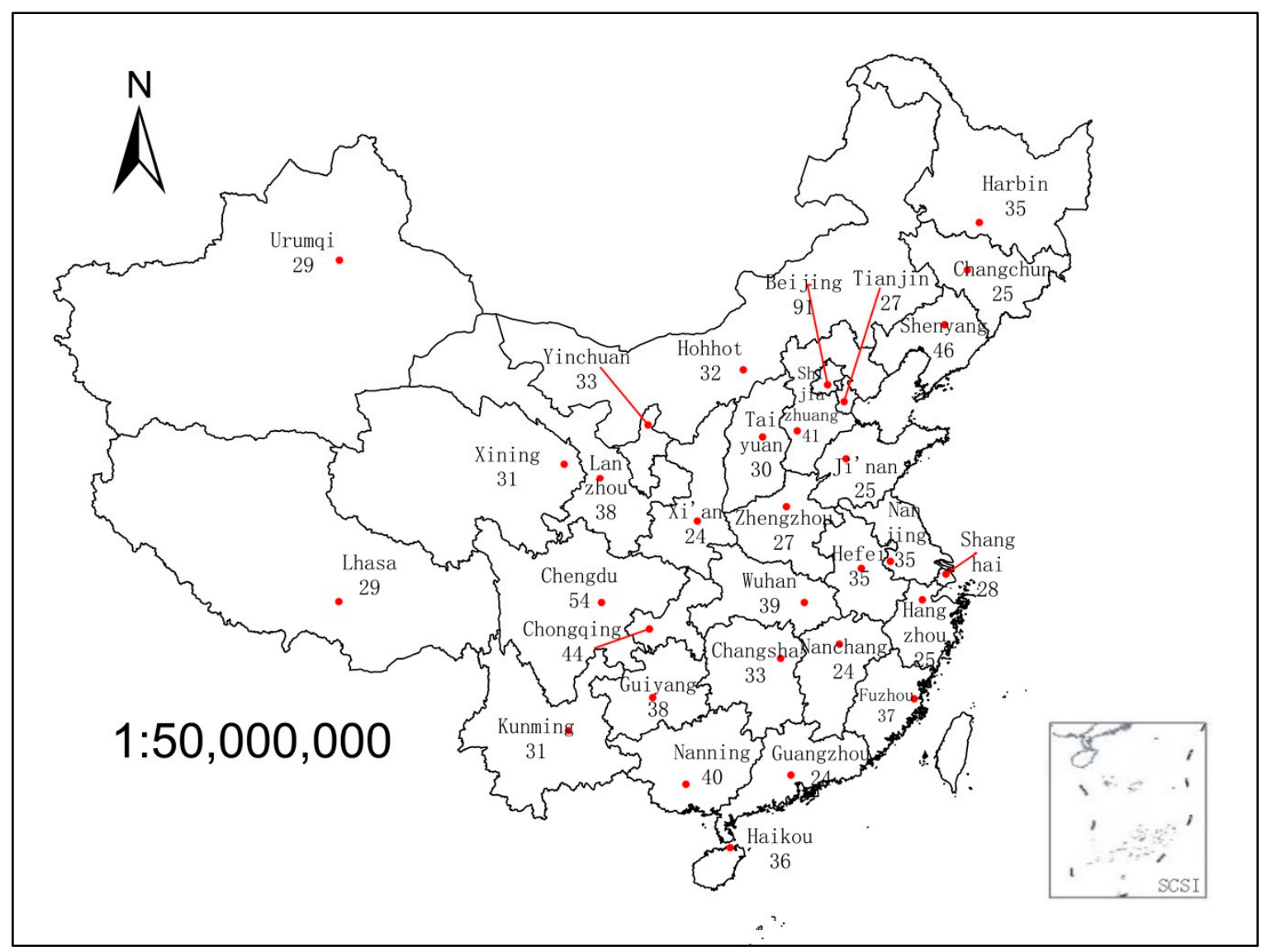

Figure 1. Amounts and distribution of data for each provincial capital city in China from 2006 to 2018.

\subsection{Calculating the Loading Capacity of SS for Forestry Application}

The soil environmental capacity for metals is the maximum amount that the soil can load in certain regions and periods, and to know this capacity is crucial to control the amount of metals brought in via SS application. As an ecosystem, soil can decrease the concentrations of pollutants and their accumulation [40]. Thus, we adopted the soil dynamic environmental capacity $\left(Q_{n}\right)$ when SS is used in long-term application programs in forestry. The $Q_{n}$ is defined by the following equation $[41,42]$ :

$$
Q_{n}=2.25 \times 10^{6} \times\left(S_{i}-C_{i} K^{n}\right)(1-K) /\left[K\left(1-K^{n}\right)\right] \times 10^{-6},
$$

where $Q_{n}$ is the soil dynamic environmental capacity, $\mathrm{kg} \cdot \mathrm{ha}^{-1} \cdot \mathrm{y}^{-1} ; 2.25 \times 10^{6}$ is the average mass of surface soil $(0-20 \mathrm{~cm})$ per hectare, $\left(\mathrm{kg} \cdot \mathrm{ha}^{-1}\right) ; i$ represents the certain metal of the eight metal elements; $S_{i}$ is the risk screening value for soil contamination of metal $i,\left(\mathrm{mg} \cdot \mathrm{kg}^{-1}\right)$, adopting the other criteria for forestry soil in GB 15618-2018 (Table 1) [43]; $C_{i}$ is the baseline value of soil metal $i,\left(\mathrm{mg}^{\circ} \cdot \mathrm{kg}^{-1}\right) ; \mathrm{K}$ is the 
residual rate of the soil metal, which is associated with the absorption of plants, soil loss, and leaching and generally amounts to 0.90 [44]; $n$ is the time (here, 15 years); and $10^{-6}$ is the unit scaling factor.

Table 1. Risk screening values for soil and limits for sewage sludge (SS).

\begin{tabular}{|c|c|c|c|c|c|c|}
\hline \multirow{3}{*}{ Metal } & & & & & \multicolumn{2}{|c|}{ Unit: $\mathrm{mg} \cdot \mathrm{kg}^{-1}$} \\
\hline & \multicolumn{4}{|c|}{ Risk Screening Values for Soil } & \multicolumn{2}{|c|}{ Limits for SS } \\
\hline & $\mathrm{pH} \leq 5.5$ & $5.5<\mathrm{pH} \leq 6.5$ & $6.5<\mathrm{pH} \leq 7.5$ & $\mathrm{pH}>7.5$ & $<6.5$ & $\geq 6.5$ \\
\hline As & 40 & 40 & 30 & 25 & 75 & 75 \\
\hline $\mathrm{Cd}$ & 0.3 & 0.3 & 0.3 & 0.6 & 5 & 20 \\
\hline $\mathrm{Cr}$ & 150 & 150 & 200 & 250 & 600 & 1000 \\
\hline $\mathrm{Cu}$ & 50 & 50 & 100 & 100 & 800 & 1,00 \\
\hline $\mathrm{Hg}$ & 1.3 & 1.8 & 2.4 & 3.4 & 5 & 15 \\
\hline $\mathrm{Ni}$ & 60 & 70 & 100 & 190 & 100 & 200 \\
\hline $\mathrm{Pb}$ & 70 & 90 & 120 & 170 & 300 & 1000 \\
\hline $\mathrm{Zn}$ & 200 & 200 & 250 & 300 & 2000 & 4000 \\
\hline
\end{tabular}

Note: Risk screening values for soil and limits for SS data were derived from GB 15618-2018 and GB/T 23486-2009, respectively.

The loading capacity of SS for forestry application in PCC was calculated by the following equations:

$$
\begin{gathered}
S_{n}=Q_{n} / \mathrm{W}_{s i} \times 10^{3} \\
T=S_{\text {min }} \times A F \times 10^{-6}
\end{gathered}
$$

where $S_{n}$ is the $i$ threshold of the metal of SS for forestry application, $\mathrm{t} \cdot \mathrm{ha}^{-1} \cdot \mathrm{y}^{-1} ; W_{s i}$ is the $i$ concentration of SS (meeting the requirements GB/T 23486-2009 [45] in Table 1), $\mathrm{mg}^{-\mathrm{kg}^{-1}}$; $T$ is the loading capacity of $\mathrm{SS}$ for forestry application, million $\mathrm{t} \cdot \mathrm{y}^{-1} ; S_{\min }$ is the priority control threshold (minimum value of eight $\left.S_{n} \mathrm{~s}\right) ; A F$ is the area of forestry in PCC, (ha); and $10^{3}$ and $10^{-6}$ are the unit scaling factors.

\section{Results}

\subsection{Spatial Distribution of Metals in SS}

All PCCs' SS met the requirements established in the GB/T 23486-2009 (Figure 2).

The As concentrations ranged between 9.27 and $48.33 \mathrm{mg} \cdot \mathrm{kg}^{-1}$, with a mean value of $19.05 \mathrm{mg} \cdot \mathrm{kg}^{-1}$. They exceeded $30 \mathrm{mg} \cdot \mathrm{kg}^{-1}$ in Hangzhou, Beijing, Shanghai, Guangzhou, and Xi'an. In five southwestern PCCs, the As concentrations of SS ranged between 20 and $30 \mathrm{mg} \cdot \mathrm{kg}^{-1}$, while in about one-third of the PCCs, they ranged from 10 to $20 \mathrm{mg} \cdot \mathrm{kg}^{-1}$. In contrast, in Nanjing and Chongqing, the levels were below $10 \mathrm{mg} \cdot \mathrm{kg}^{-1}$.

The Cd concentrations showed a range of 1.70 to $7.13 \mathrm{mg} \cdot \mathrm{kg}^{-1}$, with an average value of $3.84 \mathrm{mg} \cdot \mathrm{kg}^{-1}$. Most of the PCCs with lower Cd levels were located in industrial zones of such as Beijing, Shanghai, Tianjin, Guangzhou, Harbin, Changchun, Zhengzhou, and Chengdu. The Cd concentrations in Xi'an, Shijiazhuang, Kunming, and Hangzhou ranged from 6.0 to $7.5 \mathrm{mg} \cdot \mathrm{kg}^{-1}$; PCCs with Cd concentrations from 4.5 to $6 \mathrm{mg} \cdot \mathrm{kg}^{-1}$ and 3 to $4.5 \mathrm{mg} \cdot \mathrm{kg}^{-1}$ accounted for one-third of all PCCs.

Regarding the $\mathrm{Cr}$ concentrations, we observed a range of 77.03 to $481.86 \mathrm{mg} \cdot \mathrm{kg}^{-1}$, with an average value of $172.26 \mathrm{mg} \cdot \mathrm{kg}^{-1}$; the highest level was found for Tianjin. Sewage sludge from Hangzhou, Xi'an, and Shanghai had Cr levels of $369.28,343.62$, and $307.20 \mathrm{mg} \mathrm{kg}^{-1}$, respectively. In four PCCs, the levels ranged from 200 to $300 \mathrm{mg} \cdot \mathrm{kg}^{-1}$, although $\mathrm{Cr}$ concentrations mainly varied from 100 to $200 \mathrm{mg} \cdot \mathrm{kg}^{-1}$. In Nanchang, Shenyang, Beijing, Harbin, and Nanjing, the Cr levels were below $100 \mathrm{mg} \cdot \mathrm{kg}^{-1}$. 

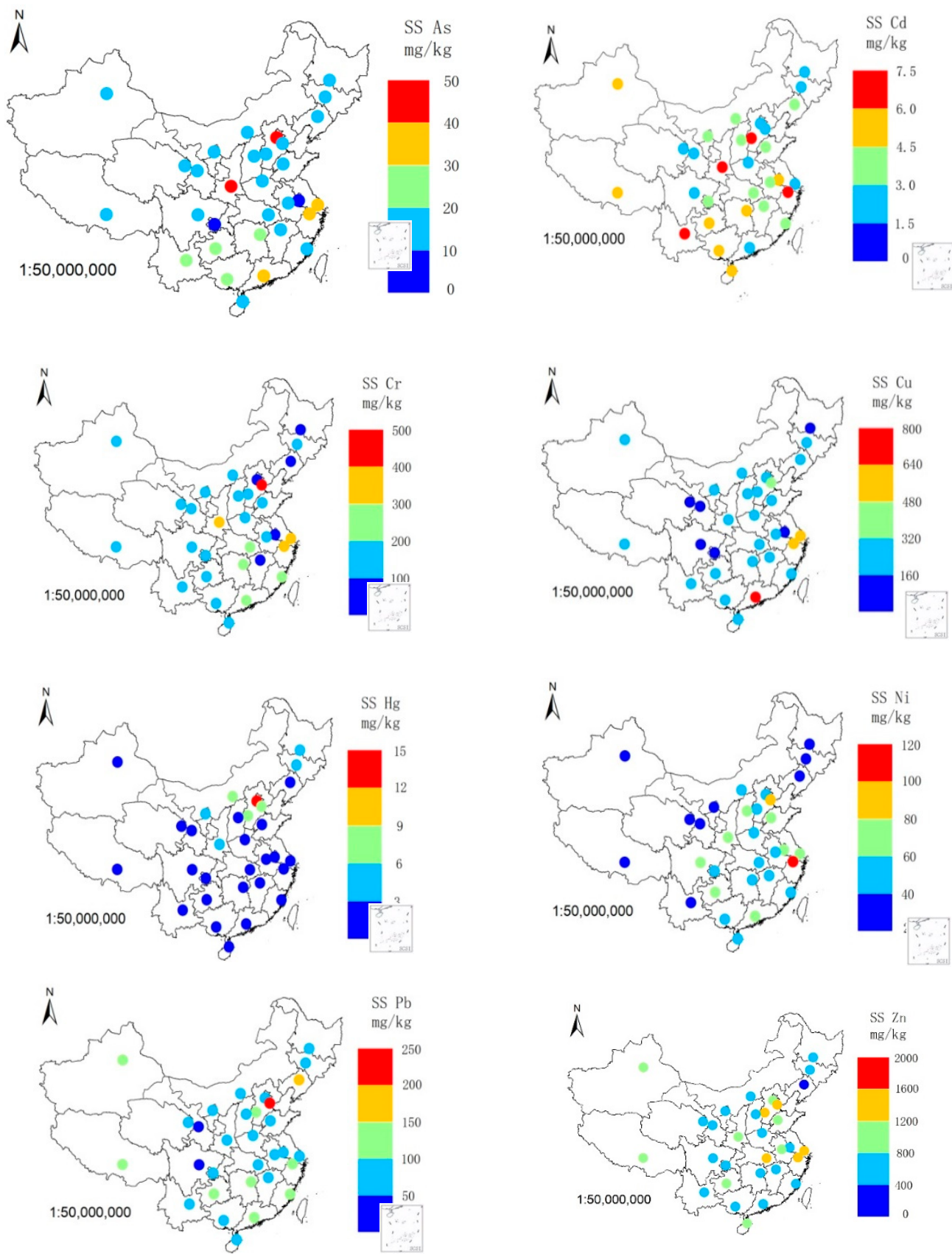

Figure 2. Spatial distribution of metal concentrations of sewage sludge for 31 provincial capital cities.

The minimum and maximum $\mathrm{Cu}$ concentrations were 99.21 and $751.6 \mathrm{mg} \cdot \mathrm{kg}^{-1}$, respectively, with a mean value of $258.47 \mathrm{mg} \cdot \mathrm{kg}^{-1}$. In most PCCs, the Cu concentrations of SS were below $500 \mathrm{mg} \cdot \mathrm{kg}^{-1}$. In Wuhan, Haikou, Tianjin, and Shanghai, the levels ranged from 300 to $500 \mathrm{mg} \cdot \mathrm{kg}^{-1}$; the minimum value was found for Lanzhou.

The $\mathrm{Hg}$ concentrations ranged between 1.13 and $12.42 \mathrm{mg} \cdot \mathrm{kg}^{-1}$, with a mean value of $3.06 \mathrm{mg} \cdot \mathrm{kg}^{-1}$. In contrast to the $\mathrm{Cd}$ distribution, the PCCs with the highest concentrations were located in highly industrialized areas such as Beijing, Tianjin, Shijiazhuang, Harbin, and Changchun. In 23 PCCs, the Hg concentrations of SS were below $3 \mathrm{mg} \cdot \mathrm{kg}^{-1}$.

For the Ni concentrations, we observed a range from 22.54 to $111.01 \mathrm{mg} \cdot \mathrm{kg}^{-1}$, with an average value of $53.43 \mathrm{mg} \cdot \mathrm{kg}^{-1}$. In most PCCs, the Ni concentrations of SS were below $100 \mathrm{mg} \cdot \mathrm{kg}^{-1}$, with the exception of Hangzhou. In Tianjin, the Ni level of SS was $87.17 \mathrm{mg} \cdot \mathrm{kg}^{-1}$. The PCCs with concentrations ranging from 60 to $80 \mathrm{mg} \cdot \mathrm{kg}^{-1}$ and from 40 to $60 \mathrm{mg} \cdot \mathrm{kg}^{-1}$ accounted for one-third of all PCCs. 
In the northwestern and northeastern areas, Ni concentrations in SS were more than 20 and less than $40 \mathrm{mg} \cdot \mathrm{kg}^{-1}$.

The $\mathrm{Pb}$ concentrations varied between 34.27 and $241.80 \mathrm{mg} \cdot \mathrm{kg}^{-1}$; the mean value was $92.35 \mathrm{mg} \cdot \mathrm{kg}^{-1}$. The highest level was observed for Tianjin, followed by Shenyang. In seven PCCs, the Pb levels of SS ranged from 100 to $200 \mathrm{mg} \cdot \mathrm{kg}^{-1}$, while in two-thirds of the PCCs, the levels were between 50 and $100 \mathrm{mg} \cdot \mathrm{kg}^{-1}$. For Chengdu and Lanzhou, we observed levels below $50 \mathrm{mg} \cdot \mathrm{kg}^{-1}$.

The minimum and maximum $\mathrm{Zn}$ concentrations were 376.80 and $2024.53 \mathrm{mg} \cdot \mathrm{kg}^{-1}$, respectively, with a mean value of $870.15 \mathrm{mg} \cdot \mathrm{kg}^{-1}$. Similar to the $\mathrm{Hg}$ distribution, the PCCs with the highest concentrations were located in industrial areas such as Tianjin, Hangzhou, Shijiazhuang, Wuhan, and Shanghai. In eight PCCs, the Zn levels of SS ranged from 800 to $1200 \mathrm{mg} \cdot \mathrm{kg}^{-1}$, while in 17 PCCs, the range was 400 to $800 \mathrm{mg} \cdot \mathrm{kg}^{-1}$. For Shenyang, the lowest $\mathrm{Zn}$ concentration of about $400 \mathrm{mg} \cdot \mathrm{kg}^{-1}$ was observed.

\subsection{Threshold of SS for Forestry Application, $S_{n}$}

As shown in Figure 3, the $S_{n}$ s values of eight metals differed within the same PCC, while those of certain metals differed among 31 PCCs. By screening the smallest three $S_{n}$ s values for each PCC, we found that two of them appeared for $\mathrm{Cd}$ and $\mathrm{Zn}$, while the other ones appeared for $\mathrm{Cu}$, except for As in Xi'an and $\mathrm{Hg}$ in Beijing, Shijiazhuang, and Hohhot. Based on the $S_{n} \mathrm{~s}$ values, the priority control metals were Cd (27 cities), $\mathrm{Cu}$ (Shanghai and Guangzhou), Hg (Beijing), and Zn (Tianjin).

The $S_{n} \mathrm{~s}$ values of As varied from $116 \mathrm{t} \cdot \mathrm{ha}^{-1} \cdot \mathrm{y}^{-1}$ in Xi' an to $1292 \mathrm{t} \cdot \mathrm{ha}^{-1} \cdot \mathrm{y}^{-1}$ in Chongqing. In 11 PCCs, the values exceeded $592 \mathrm{t} \cdot \mathrm{ha}^{-1} \cdot \mathrm{y}^{-1}$, while in Shenyang, Wuhan, and Fuzhou, the values exceeded $1000 \mathrm{t} \cdot \mathrm{ha}^{-1} \cdot \mathrm{y}^{-1}$. In Hangzhou, the $S_{n}$ value was below $200 \mathrm{t} \cdot \mathrm{ha} \mathrm{a}^{-1} \cdot \mathrm{y}^{-1}$.

The $S_{n} \mathrm{~s}$ of Cd ranged between 7 and $91 \mathrm{t} \cdot \mathrm{ha}^{-1} \cdot \mathrm{y}^{-1}$, with $50 \%$ of the $S_{n} \mathrm{~s}$ values being above the average of $35 \mathrm{t} \cdot \mathrm{ha}^{-1} \cdot \mathrm{y}^{-1}$. In Lanzhou and Shanghai, the $S_{n} \mathrm{~s}$ values were above $70 \mathrm{t} \cdot \mathrm{ha} \mathrm{a}^{-1} \cdot \mathrm{y}^{-1}$, while in Changsha and Kunming, they were below $10 \mathrm{t} \cdot \mathrm{ha}^{-1} \cdot \mathrm{y}^{-1}$.

The $S_{n} \mathrm{~s}$ of $\mathrm{Cr}$ ranged from 152 to $958 \mathrm{t} \cdot \mathrm{ha}^{-1} \cdot \mathrm{y}^{-1}$, and $50 \%$ of the $S_{n} \mathrm{~s}$ values were above the average of $397 \mathrm{t} \cdot \mathrm{ha}^{-1} \cdot \mathrm{y}^{-1}$. In Hohhot $\left(628 \mathrm{t} \cdot \mathrm{ha} \mathrm{a}^{-1} \cdot \mathrm{y}^{-1}\right)$ and Nanjing $\left(958 \mathrm{t} \cdot \mathrm{ha}^{-1} \cdot \mathrm{y}^{-1}\right)$, the values were above $600 \mathrm{t} \cdot \mathrm{ha}^{-1} \cdot \mathrm{y}^{-1}$, while they were below $200 \mathrm{t} \cdot \mathrm{ha}^{-1} \cdot \mathrm{y}^{-1}$ in Tianjin, Hangzhou, Changsha, Wuhan, Xi'an, Guangzhou, and Fuzhou.

The minimum $S_{n}$ of $\mathrm{Cu}$ was $18 \mathrm{t} \cdot \mathrm{ha}^{-1} \cdot \mathrm{y}^{-1}$ in Guangzhou, while the maximum level was $301 \mathrm{t} \cdot \mathrm{ha}^{-1} \cdot \mathrm{y}^{-1}$ in Lanzhou; one-third of the $S_{n} \mathrm{~s}$ values were above the average of $104 \mathrm{t} \cdot \mathrm{ha}^{-1} \cdot \mathrm{y}^{-1}$. Nanjing's $S_{n}$ value was $263 \mathrm{t} \cdot \mathrm{ha} \mathrm{a}^{-1} \cdot \mathrm{y}^{-1}$, while those of the other cities were above $40 \mathrm{t} \cdot \mathrm{ha}^{-1} \cdot \mathrm{y}^{-1}$ and below $200 \mathrm{t} \cdot \mathrm{ha}^{-1} \cdot \mathrm{y}^{-1}$.

For $\mathrm{Hg}$, the $S_{n} \mathrm{~s}$ values varied from $42 \mathrm{t} \cdot \mathrm{ha}^{-1} \cdot \mathrm{y}^{-1}$ in Beijing to $759 \mathrm{t} \cdot \mathrm{ha}^{-1} \cdot \mathrm{y}^{-1}$ in Guiyang, with one-third of the values being higher than the average $305 \mathrm{t} \cdot \mathrm{ha} \mathrm{A}^{-1} \cdot \mathrm{y}^{-1}$. The $S_{n} \mathrm{~S}$ values in Shanghai and Lanzhou had Hg levels of 604 and $5221 \mathrm{t} \cdot \mathrm{ha}^{-1} \cdot \mathrm{y}^{-1}$, respectively, while the levels were above $400 \mathrm{t} \cdot \mathrm{ha}^{-1} \cdot \mathrm{y}^{-1}$ in Urumqi, Ji'nan, and Lhasa. Only Beijing's $S_{n}$ value was below $100 \mathrm{t} \cdot \mathrm{ha}^{-1} \cdot \mathrm{y}^{-1}$.

The $S_{n}$ s values of Ni ranged between 216 and $2582 \mathrm{t} \cdot \mathrm{ha}^{-1} \cdot \mathrm{y}^{-1}$, with an average of $728 \mathrm{t} \cdot \mathrm{ha}^{-1} \cdot \mathrm{y}^{-1}$. The values were above $1000 \mathrm{t} \cdot \mathrm{ha}^{-1} \cdot \mathrm{y}^{-1}$ in Hohhot $\left(1035 \mathrm{t} \cdot \mathrm{ha}^{-1} \cdot \mathrm{y}^{-1}\right)$, Shijiazhuang $\left(1044 \mathrm{t} \cdot \mathrm{ha}^{-1} \cdot \mathrm{y}^{-1}\right)$, Lhasa (1449 tha $\left.{ }^{-1} \cdot \mathrm{y}^{-1}\right)$, Yinchuan (1711 $\left.\mathrm{t} \cdot \mathrm{ha}^{-1} \cdot \mathrm{y}^{-1}\right)$, Urumqi $\left(1747 \mathrm{t} \cdot \mathrm{ha} \mathrm{a}^{-1} \cdot \mathrm{y}^{-1}\right)$, and Lanzhou $\left(2582 \mathrm{t} \cdot \mathrm{ha}^{-1} \cdot \mathrm{y}^{-1}\right)$ and below $300 \mathrm{t} \cdot \mathrm{ha}^{-1} \cdot \mathrm{y}^{-1}$ in Chengdu, Hangzhou, and Guangzhou.

The $S_{n}$ s levels of $\mathrm{Pb}$ ranged from $143 \mathrm{to} 1522 \mathrm{t} \cdot \mathrm{ha}^{-1} \cdot \mathrm{y}^{-1}$ (average $439 \mathrm{t} \cdot \mathrm{ha}^{-1} \cdot \mathrm{y}^{-1}$ ) and were above $600 \mathrm{t} \cdot \mathrm{ha}^{-1} \cdot \mathrm{y}^{-1}$ in Hohhot $\left(613 \mathrm{t} \cdot \mathrm{ha}^{-1} \cdot \mathrm{y}^{-1}\right)$, Zhengzhou $\left(672 \mathrm{t} \cdot \mathrm{ha}^{-1} \cdot \mathrm{y}^{-1}\right)$, Shanghai $\left(718 \mathrm{t} \cdot \mathrm{ha} \mathrm{a}^{-1} \cdot \mathrm{y}^{-1}\right)$, Nanjing (881 th.ha $\left.\mathrm{a}^{-1} \cdot \mathrm{y}^{-1}\right)$, and Lanzhou (1522 $\left.\mathrm{t} \cdot \mathrm{ha}^{-1} \cdot \mathrm{y}^{-1}\right)$. In Guangzhou, Changsha, Shenyang, and Fuzhou, the $S_{n}$ s values were between 140 and $200 \mathrm{t} \cdot \mathrm{ha}^{-1} \cdot \mathrm{y}^{-1}$.

The minimum and maximum $S_{n}$ s levels of Zn were $36 \mathrm{t} \cdot \mathrm{ha}^{-1} \cdot \mathrm{y}^{-1}$ in Wuhan and $216 \mathrm{t} \cdot \mathrm{ha}^{-1} \cdot \mathrm{y}^{-1}$ in Lanzhou, respectively, with an average of $95 \mathrm{t} \cdot \mathrm{ha}^{-1} \cdot \mathrm{y}^{-1}$. The remaining $S_{n} \mathrm{~s}$ levels ranged between 50 and $100 \mathrm{t} \cdot \mathrm{ha}^{-1} \cdot \mathrm{y}^{-1}$. 


\begin{tabular}{|c|c|c|c|c|c|c|c|c|}
\hline PCC & As & Cd & $\mathrm{Cr}$ & $\mathrm{Cu}$ & $\mathrm{Hg}$ & $\mathrm{Ni}$ & $\mathrm{Pb}$ & $\mathrm{Zn}$ \\
\hline Beijing & 278 & 51 & 516 & 70 & 42 & 357 & 387 & 54 \\
\hline Changchun & 810 & 38 & 437 & 72 & 118 & 525 & 296 & 82 \\
\hline Changsha & 398 & 7 & 163 & 59 & 231 & 367 & 159 & 92 \\
\hline Chengdu & 753 & 43 & $356 \mid$ & 96 & 181 & 216 & 485 & 68 \\
\hline Chongqing & 1292 & 22 & 432 & 128 & 201 & 300 & 318 & 119 \\
\hline Fuzhou & 1114 & 24 & 199 & 52 & 243 & 348 & 193 & 80 \\
\hline Guangzhou & 388 & 35 & 182 & 18 & 245 & 273 & 143 & 73 \\
\hline Guiyang & 235 & 26 & 527 & 132 & 759 & 943 & 348 & 84 \\
\hline Haikou & 936 & 19 & 336 & 46 & 234 & 381 & 248 & 51 \\
\hline Hangzhou & 184 & 14 & 161 & 50 & 360 & 271 & 316 & 50 \\
\hline Harbin & $883 \mid$ & 37 & 540 & 101 & 156 & 748 & 519 & 80 \\
\hline Hefei & 890 & 23 & 352 & 50 & 369 & 414 & $347 \mid$ & 52 \\
\hline Hohhot & 486 & 57 & 628 & 155 & 142 & 1035 & 613 & 124 \\
\hline Jinan & 634 & 48 & 458 & 109 & 480 & 841 & 592 & 112 \\
\hline Kunming & 410 & 9 & 339 & 48 & 232 & 489 & 352 & 106 \\
\hline Lanzhou & 500 & 91 & 506 & 301 & 522 & 2582 & 1522 & 216 \\
\hline Lhasa & 471 & 37 & $525 \mid$ & 145 & 485 & 1449 & 504 & 99 \\
\hline Nanchang & 983 & 23 & $445 \mid$ & 60 & 352 & 390 & $257 \mid$ & 87 \\
\hline Nanjing & 802 & 36 & 958 & 263 & 345 & 946 & 881 & 155 \\
\hline Nanning & 572 & 14 & 411 & 56 & 236 & 359 & 314 & 88 \\
\hline Shanghai & 235 & 91 & $237 \mid$ & 57 & 604 & 752 & 718 & 68 \\
\hline Shenyang & 1012 & 13 & 494 & 55 & 284 & 596 & 158 & 148 \\
\hline Shijiazhuang & 521 & 25 & 568 & 150 & 141 & 1044 & 459 & 56 \\
\hline Taiyuan & 318 & 20 & 336 & 178 & 381 & 390 & 408 & 107 \\
\hline Tianjin & 422 & 69 & 152 & 63 & 122 & 668 & 213 & 62 \\
\hline Urumqi & 482 & 37 & $481 \mid$ & 119 & 437 & 747 & 412 & 83 \\
\hline Wuhan & 1061 & 22 & 164 & 44 & 360 & 380 & 316 & 36 \\
\hline Xi'an & 116 & 11 & 169 & 141 & 180 & 439 & 382 & 76 \\
\hline Xining & 380 & 36 & 363 & 193 & 345 & 981 & 528 & 156 \\
\hline Yinchuan & 436 & 55 & $535 \mid$ & 112 & 288 & 1711 & 552 & 178 \\
\hline Zhengzhou & 355 & 43 & 350 & 108 & 377 & 627 & 672 & 112 \\
\hline Anverage & 592 & 35 & 397 & 104 & 305 & 728 & 439 & 95 \\
\hline
\end{tabular}

Figure 3. Threshold levels of the different metals for sewage sludge application to forests in 31 provincial capital cities. Unit: $\mathrm{t} \cdot \mathrm{ha}^{-1} \cdot \mathrm{y}^{-1}$, Note: Values in red represent thresholds for priority control metal, Smin.

\subsection{Loading Capacity of SS for Forestry Application}

The $S_{\min } \mathrm{s}$ varied from 7 to $91 \mathrm{t} \cdot \mathrm{ha} \mathrm{a}^{-1} \cdot \mathrm{y}^{-1}$, with an average of $33 \mathrm{t} \cdot \mathrm{ha}^{-1} \cdot \mathrm{y}^{-1}$ in 31 PCCs, distributed between 10 and $50 \mathrm{t} \cdot \mathrm{ha}^{-1} \cdot \mathrm{y}^{-1}$ and accounting for $80 \%$ (Table 2). Among them, the $S_{\min } \mathrm{s}$ of $50 \%$ of the PCCs were higher than $30 \mathrm{t} \cdot \mathrm{ha}^{-1} \cdot \mathrm{y}^{-1}$ (CJ-T 362-2011). The $S_{\min }$ of Lanzhou was $91 \mathrm{t} \cdot \mathrm{ha}^{-1} \cdot \mathrm{y}^{-1}$, followed by those of Tianjin $\left(62 \mathrm{t} \cdot \mathrm{ha}^{-1} \cdot \mathrm{y}^{-1}\right)$ and Hohhot, Shanghai, and Yinchuan, with values of 57,57 , and $55 \mathrm{t} \cdot \mathrm{ha}^{-1} \cdot \mathrm{y}^{-1}$, respectively. There were five and six PCCs with $S_{\min }$ values from 40 to $50 \mathrm{t} \cdot \mathrm{ha} \mathrm{a}^{-1} \cdot \mathrm{y}^{-1}$ and 30 to $40 \mathrm{t} \cdot \mathrm{ha} \mathrm{a}^{-1} \cdot \mathrm{y}^{-1}$, respectively. In seven PCCs, the values ranged from 20 to $30 \mathrm{t} \cdot \mathrm{ha}^{-1} \cdot \mathrm{y}^{-1}$, including Shijiazhuang, Chongqing, and Wuhan. In Taiyuan, Haikou, Guangzhou, 
Nanning, Hangzhou, Shenyang, and Xi'an, the $S_{\min }$ values were below $20 \mathrm{t} \cdot \mathrm{ha}^{-1} \cdot \mathrm{y}^{-1}$, while those of Kunming and Changsha were 9 and $7 \mathrm{t} \cdot h \mathrm{a}^{-1} \cdot \mathrm{y}^{-1}$, respectively.

Table 2. Loading capacities of sewage sludge in 31 provincial capital cities.

\begin{tabular}{|c|c|c|c|}
\hline PCC & $S_{\min }\left(t \cdot h a^{-1} \cdot y^{-1}\right)$ & Forest Area $\left(10^{4}\right.$ ha) & Loading Capacity (Million $\mathbf{t} \cdot \mathbf{y}^{-1}$ ) \\
\hline Harbin & 37 & 244 & 90.2 \\
\hline Chongqing & 22 & 374 & 83.4 \\
\hline Beijing & 42 & 76.8 & 32.5 \\
\hline Hohhot & 57 & 43.2 & 24.8 \\
\hline Changchun & 38 & 63.1 & 24.0 \\
\hline Chengdu & 43 & 55.0 & 23.8 \\
\hline Lasa & 37 & 57.6 & 21.5 \\
\hline Lanzhou & 91 & 20.9 & 19.1 \\
\hline Fuzhou & 24 & 72.4 & 17.5 \\
\hline Hangzhou & 14 & 113 & 15.6 \\
\hline Nanning & 14 & 106 & 15.3 \\
\hline Ji'nan & 48 & 28.2 & 13.6 \\
\hline Shijiazhuang & 25 & 51.6 & 13.0 \\
\hline Zhengzhou & 43 & 23.7 & 10.2 \\
\hline Guiyang & 26 & 39.3 & 10.1 \\
\hline Kunming & 9 & 103 & 9.1 \\
\hline Xining & 36 & 24.5 & 8.9 \\
\hline Yinchuan & 55 & 14.4 & 8.0 \\
\hline Hefei & 23 & 33.1 & 7.7 \\
\hline Urumqi & 37 & 20.9 & 7.7 \\
\hline Tianjin & 62 & 11.1 & 6.9 \\
\hline Guangzhou & 18 & 31.5 & 5.8 \\
\hline Xi'an & 11 & 48.5 & 5.5 \\
\hline Wuhan & 22 & 24.0 & 5.3 \\
\hline Shenyang & 13 & 39.9 & 5.1 \\
\hline Changsha & 7 & 64.8 & 4.6 \\
\hline Shanghai & 41 & 10.3 & 4.2 \\
\hline Nanchang & 23 & 16.9 & 3.9 \\
\hline Nanjing & 36 & 10.3 & 3.7 \\
\hline Taiyuan & 20 & 16.1 & 3.2 \\
\hline Haikou & 19 & 8.8 & 1.6 \\
\hline
\end{tabular}

Note: Forest area data were derived from publicly available information.

The forest areas in the 31 PCCs varied from $8.76 \times 10^{4}$ (Haikou) to $374 \times 10^{4}$ ha (Chongqing), with an average of $59.6 \times 10^{4}$ ha. Most AFs in the PCCs were between $10 \times 10^{4}$ and $80 \times 10^{4}$ ha. Harbin had the second largest forest area of $244 \times 10^{4}$ ha. In three PCCs, namely Kunming, Nanning, and Hangzhou, the forest area was above $100 \times 10^{4}$ ha. In Beijing, Fuzhou, Changsha, Changchun, Lhasa, Chengdu, and Shijiazhuang, the forest area ranged from $50 \times 10^{4}$ to $80 \times 10^{4}$ ha. Half of the forest areas were between $20 \times 10^{4}$ and $50 \times 10^{4}$ ha, while in Haikou, this area accounted for less than $10 \times 10^{4}$ ha.

The loading capacities varied from 1.6 million $\mathrm{t} \cdot \mathrm{y}^{-1}$ (Haikou) to 90.2 million $\mathrm{t} \cdot \mathrm{y}^{-1}$ (Harbin), with an average of 16.4 million $t \cdot \mathrm{y}^{-1}$ in 31 PCCs; the total loading capacity reached 507 million $t \cdot \mathrm{y}^{-1}$. Chongqing had the second largest loading capacity, equaling 83.4 million $t \cdot y^{-1}$. Beijing's loading capacity was slightly above 30 million $t \cdot y^{-1}$. In Hohhot, Changchun, Chengdu, and Lhasa, loading capacities were between 20 and 30 million $t \cdot y^{-1}$, while in the following eight PCCs, the loading capacities were over 10 million $\mathrm{t} \cdot \mathrm{y}^{-1}$ : Lanzhou, Fuzhou, Hangzhou, Nanning, Jinan, Shijiazhuang, Zhengzhou, and Guiyang. The PCCs with loading capacities below 10 million $t \cdot y^{-1}$ accounted for $50 \%$. Tianjin's, Shanghai's, and Guangzhou's loading capacities were 6.9, 5.9, and 5.8 million $\mathrm{t} \cdot \mathrm{y}^{-1}$, respectively. Loading capacities were also lower than 5 million $\mathrm{t} \cdot \mathrm{y}^{-1}$ in Changsha, Nanchang, Nanjing, and Taiyuan. 


\section{Discussion}

The application of sewage sludge in forestry is common in several countries around the world [46]. In so-called "sludge landscaping", treated sludge is applied to cultivated soil, as a soil amendment, and to urban or suburban woodland as organic fertilizer (including municipal green belts, woodlands, grasslands, parks, seedling bases, highway isolation zones, stadiums, etc.), promoting tree growth and improving the ornamental quality of flowers. In the US, municipal sludge is widely used in gardening and applied to parks, grasslands, and ornamental woodlands. China has also started to apply sewage sludge in landscaping, and sewage sludge treatment and disposal in Beijing, Shanghai, and Guangzhou have received increased attention [47]. So far, several studies have dealt with the responses of the soil-forestry systems to the application of sewage sludge. For example, in a greenhouse pot experiment, a mix of sewage sludge and garden waste compost changed the form of metals in the soil [48]. Wang et al. [49] analyzed the effects of applying excess sludge of the Shenyang North Sewage Treatment Plant to grassland and showed that the organic matter content in the soil increased by $12.79-80.80 \%$, the biomass of the grassland increased, and the color of the grass became more intense. Field experiments along the Haitun Expressway have shown that sludge and garbage compost can be used as additives for slope greening [50].

There are, however, only a few reports on the threshold values of metals in SS for forestry application. According to previously established guidelines, the amount of sewage sludge should not exceed $30 \mathrm{t} \cdot \mathrm{ha}^{-1} \cdot \mathrm{y}^{-1}$, and continuous application should be limited to 15 years (CJ/T 362-2011) [38]. In our study, the average $S_{\min }$ of SS for forestry application was $32.14 \mathrm{t} \cdot \mathrm{ha}^{-1} \cdot \mathrm{y}^{-1}$. However, we observed considerable regional differences among different PCCs. Generally, the $S_{\min }$ values in the southern PCCs were lower than those in the northern ones, mainly because the risk screening values for soil contamination of $\mathrm{Cd}$ are lowest $\left(0.3 \mathrm{mg} \cdot \mathrm{kg}^{-1}\right)$ in acidic soil. They also have higher $\mathrm{Cd}$ contents in soil and SS, in addition to the smallest risk screening values, resulting in levels for Changsha and Kunming below $10 \mathrm{t} \cdot \mathrm{ha}^{-1} \cdot \mathrm{y}^{-1}$. In Guiyang, the Cd levels in soil and SS were closer to those for Changsha; however, the $S_{\min }$ value was $25.76 \mathrm{~kg} \cdot \mathrm{ha}^{-1} \cdot \mathrm{y}^{-1}$ due to the risk screening values of alkaline soil. The $\mathrm{Cd}$ contents in soil and SS were low and the risk screening value was high; all three factors lead to the highest $S_{\min }$ level in Lanzhou. Risk screening values for soil contamination are determined by acid-base properties. To increase the $S_{\text {min }}$, we can start by improving the contents of metals in the soil and reducing the metals in SS.

To evaluate the loading capacity, we sorted out the quantity of treated dry SS (Q) of each PCC in 2017 (Figure 4). The larger the multiple between loading capacity and $Q$, the greater the potential of SS for forestry application in this city. The Qs varied from $0.20 \times 10^{4}$ to $31.43 \times 10^{4} \mathrm{t}$, except for Beijing $\left(137.25 \times 10^{4} \mathrm{t}\right)$, and the total $Q$ was up to $404.40 \times 10^{4} \mathrm{t}$. The total loading capacity reached 505.71 million $t \cdot y^{-1}$, being 125 times as high as the total $Q$, suggesting a great potential of SS for forestry application. Lhasa' loading capacity was $21.50 \times 10^{4}$ million $\mathrm{t} \cdot \mathrm{y}^{-1}$, and $Q$ was $0.20 \times 10^{4} \mathrm{t}$, suggesting that the former was far superior to the latter. The loading capacity in Harbin was up to 1000 times higher than its $Q$. There were four PCCs with a loading capacity more than 500 times higher as their $Q_{s}$, namely Xining (933.67 times), Fuzhou (792.71 times), Changchun (621.86 times), and Chongqing (575.41 times). The times varied from 100 to 500 in 12 PCCs, including Hohhot, Urumqi, Jinan, Chengdu, and Shijiazhuang. Loading capacities were between 80 to 100 times higher than $Q_{s}$ in Zhengzhou, $\mathrm{Xi}^{\prime}$ an, and Wuhan, while the loading capacities of Tianjin and Hangzhou were about 60 times higher than their corresponding $Q_{s}$. In Guangzhou, Haikou, Beijing, Changsha, and Shanghai, the times were $28.75,24.01,23.68,20.40$, and 14.54 , respectively. 


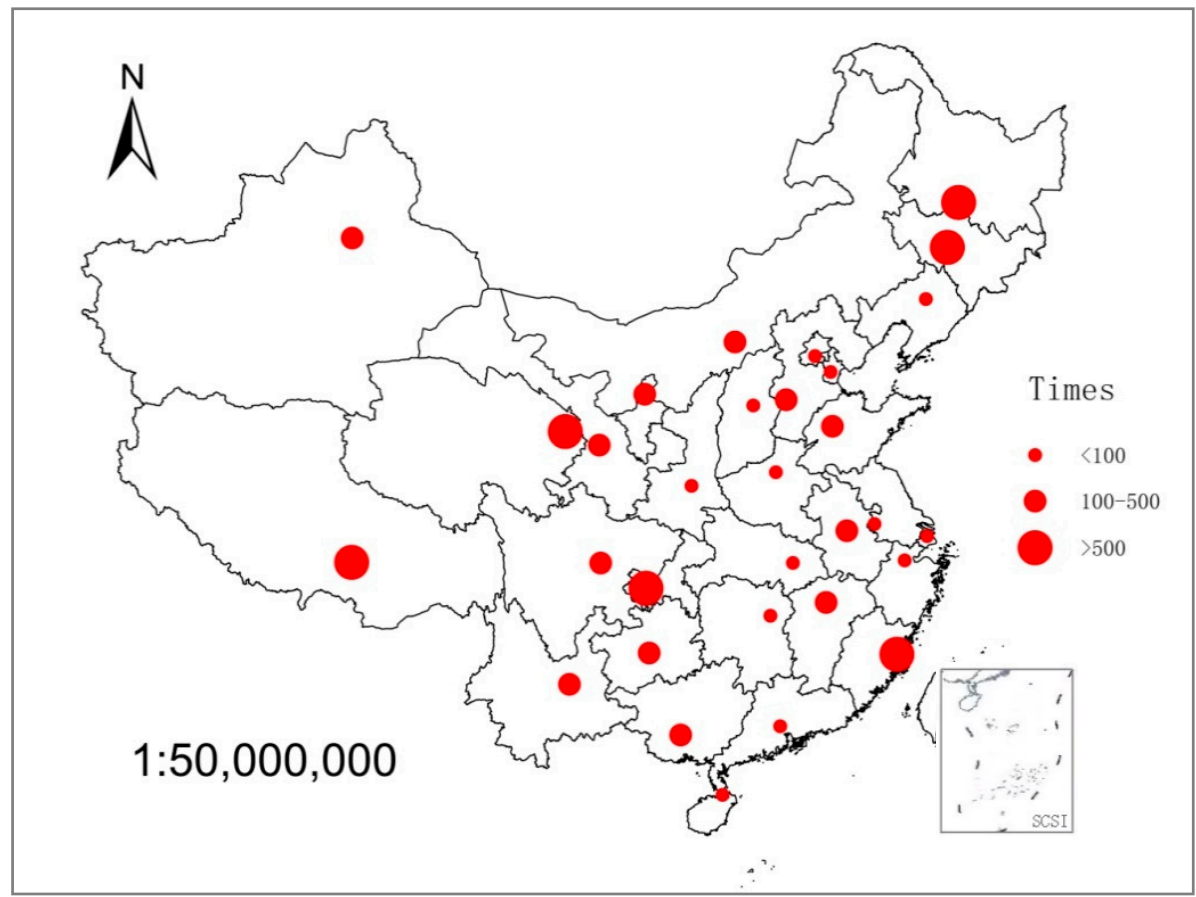

Figure 4. Differences between loading capacity and quantity of treated dry sewage sludge.

The loading capacity depended on two factors, $S_{\min }$ and $A F$. Determining these factors enables us to put forward more precise suggestions for each PCC. In Chongqing and Harbin, the high loading capacities were attributed to their largest forest areas. Beijing' loading capacity was the third largest because of its higher $S_{\min }$ and $A F$ values. Loading capacities were similar in Hohhot, Changchun, and Chengdu (about 24 million $\mathrm{t} \cdot \mathrm{y}^{-1}$ ), but Hohhot's and Chengdu's capacities were a factor of their $S_{m i n}$, while Changchun's capacity was accounted for by its $A F$. Lhasa's loading capacity was above 20 million $t \cdot y^{-1}$, mainly because of its high $\mathrm{S}_{\min }$ and $A F$ values. The loading capacity in Lanzhou was 19.1 million $\mathrm{t} \cdot \mathrm{y}^{-1}$, although its $S_{\min }$ was the highest. Loading capacities over 15 million $\mathrm{t} \cdot \mathrm{y}^{-1}$ were attributed to high AFs in Fuzhou, Hangzhou, and Nanning. Tianjin and Yinchuan had the second and the fourth largest $S_{\min }$, respectively, but their $A F s$ were slightly over $10 \times 10^{4}$ ha, which resulted in loading capacities of 6.9 and 7.7 million $t \cdot \mathrm{y}^{-1}$, respectively. By comparison, Shanghai's and Changsha's loading capacities were about 4 million $\mathrm{t} \cdot \mathrm{y}^{-1}$, caused by the $S_{\min }$ and $A F$ values, respectively. Haikou had the smallest $A F$, resulting in the lowest loading capacity.

\section{Conclusions}

Sewage sludge contains large amounts of organic matter that can improve forest soil structure and increase soil fertility, promoting plant growth. However, excessive use of SS will cause pollution to forest land. In this sense, we calculated the thresholds for the application of sewage sludge in forestry in China for the first time, considering an adequate application dose for 31 provincial capital cities. The loading capacities differed significantly among the PCCs, making it necessary to formulate specific standards for each area. The $S_{\min }$ values varied from $7 \mathrm{to} 91 \mathrm{t} \cdot \mathrm{ha} \mathrm{a}^{-1} \cdot \mathrm{y}^{-1}$, with an average of $33 \mathrm{t} \cdot \mathrm{ha}^{-1} \cdot \mathrm{y}^{-1}$ in 31 PCCs; in 50\% of the PCCs, the values were higher than $30 \mathrm{t} \cdot \mathrm{ha}^{-1} \cdot \mathrm{y}^{-1}$ (CJ-T 362-2011). The priority control metals were $\mathrm{Cu}$ in Shanghai and Guangzhou, $\mathrm{Hg}$ in Beijing, $\mathrm{Zn}$ in Tianjin, and Cd in other cities; such information facilitates the development of management strategies for the safe application of sewage sludge in forestry. Sewage sludge shows considerable potential in forestry, based on the relatively high loading capacities, albeit with differences among the different PCCs. Based on this, it is inevitable that for each region, specific sludge disposal policies are formulated. The presented results provide basic data and technical guidance for forestry application. 
Supplementary Materials: The following are available online at http://www.mdpi.com/2071-1050/12/18/7551/s1, Table S1: The data resource of metal in Provincial capital city. Table S2: The descriptive statistics of baseline and background value in provincial capital city.

Author Contributions: The study was conceived and designed by X.Z. Experiments were conducted by J.Z. and Y.L. X.Z. analyzed the data with the support of X.G. All authors reviewed and revised the manuscript to its final form. The entire study was conducted under the supervision of T.Z. All authors have read and agreed to the published version of the manuscript.

Funding: This research was funded by [Science and Technology Committee of Beijing, grant number [Z151100002115006] for providing funding for this study.

Acknowledgments: We would also like to thank the anonymous reviewers for their helpful comments and suggestions.

Conflicts of Interest: The authors declare no conflict of interest.

\section{References}

1. Yang, J.; Lei, M.; Chen, T.; Gao, D.; Zheng, G.; Guo, G.; Lee, D. Current status and developing trends of the contents of heavy metals in sewage sludges in China. Front. Environ. Sci. Eng. 2014, 5, 719-728. [CrossRef]

2. Wang, M. Land application of sewage sludge in China. Sci. Total Environ. 1997, 197, 149-160. [CrossRef]

3. Fytili, D.; Zabaniotou, A. Utilization of sewage sludge in EU application of old and new methods a review. Renew. Sustain. Energy Rev. 2008, 1, 116-140. [CrossRef]

4. Larsen, T.A.; Hoffmann, S.; Luthi, C.; Truffer, B.; Maurer, M. Emerging solutions to the water challenges of an urbanizing world. Science 2016, 352, 928-933. [CrossRef]

5. Wang, X.; Daigger, G.; Vries, M.; Ckroeze, C.; Yang, M.; Ren, N.; Liu, J.; Butler, D. Impact hotspots of reduced nutrient discharge shift across the globe with population and dietary changes. Nat. Commun. 2019, 10, 2627. [CrossRef] [PubMed]

6. Ministry of Ecology and Environment of the People's Republic of China. National Eco-Environment Bulletin; Ministry of Ecology and Environment of the People's Republic of China: Beijing, China, 2017.

7. Zhu, R.; Wu, M.; Yang, J. Mobilities and leachabilities of heavy metals in sludge with humus soil. J. Environ. Sci. 2011, 23, 247-254. [CrossRef]

8. Ashraf, M.A.; Mahmood, K.; Yusoff, I.; Qureshi, A.K. Chemical constituents of cenchrus ciliaris L. from the cholistan desert, pakistan. Arch. Biol. Sci. 2013, 4, 1473-1478. [CrossRef]

9. Kominko, H.; Gorazda, K.; Wzorek, Z. Potentiality of sewage sludge-based organo-mineral fertilizer production in poland considering nutrient value, heavy metal content and phytotoxicity for rapeseed crops. Environ. Res. 2019, 248, 109283. [CrossRef]

10. Czyżyk, F.; Rajmund, A. Influence of agricultural utilization of sludge and compost from rural wastewater treatment plant on nitrogen passes in light soil. Pol. J. Chem. Technol. 2014, 1, 1-6. [CrossRef]

11. Siebielec, G.; Siebielec, S.; Lipski, D. Long-term impact of sewage sludge, digestate and mineral fertilizers on plant yield and soil biological activity. J. Clean. Prod. 2018, 187, 372-379. [CrossRef]

12. Mohamed, B.; Olivier, G.; François, G.; Laurence, A.H.; Bourgeade, P.; Badr, A.-S.; Lotfi, A. Sewage sludge as a soil amendment in a Larix decidua plantation: Effects on tree growth and floristic diversity. Sci. Total Environ. 2018, 621, 291-301. [CrossRef] [PubMed]

13. Denaix, L.; Thomas-Chéry, A.L.; Balet, J.; Benbrahim, M.; Carnus, J.M. Effects of municipal sewage sludge application on soil and purple moor-grass (molinia caerulea) contamination by metals in a maritime pine forest. Water Air Soil Poll. 2011, 219, 239-249. [CrossRef]

14. Roy, M.; Couillard, D. Metal leaching following sludge application to a deciduous forest soil. Water Res. 1998, 5, 1642-1652. [CrossRef]

15. Khadhar, S.; Sdiri, A.; Chekirben, A.; Azouzi, R.; Charef, A. Integration of sequential extraction, chemical analysis and statistical tools for the availability risk assessment of heavy metals in sludge amended soils. Environ. Pollut. 2020, 263, 114543. [CrossRef]

16. Moffat, A.J.; Matthews, R.W.; Hall, J.E. The effects of sewage sludge on growth and foliar and soil chemistry in pole-stage corsican pine at ringwood forest, dorset UK. Can. J. For. Res. 1991, 21, 902-909. [CrossRef]

17. Sauvé, S.; Manna, S.; Turmel, M.C.; Roy, A.G.; Courchesne, F. Solid-solution partitioning of Cd, Cu, Ni, $\mathrm{Pb}$, and $\mathrm{Zn}$ in the organic horizons of a forest soil. Environ. Sci. Technol. 2003, 22, 5191-5196. [CrossRef] [PubMed] 
18. Benbrahim, M.; Denaix, L.; Thomas, A.L.; Balet, J.; Carnus, J.M. Metal concentrations in edible mushrooms following municipal sludge application on forest land. Environ. Poll. 2006, 3, 847-854. [CrossRef] [PubMed]

19. Rutgersson, C.; Ebmeyer, S.; Lassen, S.B.; Karkman, A.; Fick, J.; Kristiansson, K.; Brandt, K.K.; Flach, C.-F.; Larsson, D.G.J. Long-term application of swedish sewage sludge on farmland does not cause clear changes in the soil bacterial resistome. Environ. Int. 2020, 137, 105399. [CrossRef] [PubMed]

20. Khadhar, S.; Higshi, T.; Hamdi, H.; Matsuyama, S.; Charef, A. Distribution of 16 EPA-priority polycyclic aromatic hydrocarbons (PAHs) in sludges collected from nine Tunisian wastewater treatment plants. J. Hazard. Mater. 2010, 183, 98-102. [CrossRef]

21. Nogueira, T.A.R.; Melo, W.J.; Fonseca, I.M.; Marcussi, S.A.; Melo, G.M.P.; Marques, M.O. Fractionation of $\mathrm{Zn}, \mathrm{Cd}$ and $\mathrm{Pb}$ in a tropical soil after nine-year sewage sludge applications. Pedosphere 2010, 20, 545-556. [CrossRef]

22. Riaz, U.; Murtaza, G.; Saifullah, U.; Farooq, M. Influence of different sewage sludges and composts on growth, yield, and trace elements accumulation in rice and wheat. Land Degrad. Dev. 2018, 5, 1343-1352. [CrossRef]

23. Bourioug, M.; Gimbert, F.; Alaoui-Sehmer, L.; Benbrahim, M.; Badot, P.M.; Alaoui-Sosse, B.; Aleva, L. Effects of sewage sludge amendment on snail growth and trace metal transfer in the soil-plant-snail food chain. Environ. Sci. Poll. Res. 2015, 22, 17925-17936. [CrossRef]

24. Müller da Silva, P.H.; Poggiani, F.; Laclau, J.P. Applying sewage sludge to eucalyptus grandis plantations: Effects on biomass pro-duction and nutrient cycling through litterfall. Appl. Environ. Soil Sci. 2011, 1, 101-108.

25. Zhang, T. Studies on the Sludge Application to Forest Land. Master's Thesis, Northwestern Agricultural University, Shaanxi, China, 1992.

26. Wang, X.; Chen, T.; Ge, Y.; Jia, Y. Studies on land application of sewage sludge and its limiting factors. J. Hazard Mater. 2008, 160, 554-558. [CrossRef]

27. Wang, H.L.; Wang, C.J.; Fan, C.; Ma, M.P.; Lin, Z.K.; Wang, W.W.; Xu, Z.T.; Wang, X.D. Modification to degradation of hexazinone in forest soils amended with sewage sludge. J. Hazard. Mater. 2012, 199-200,96-104. [CrossRef]

28. Kacprzaka, M.; Neczaja, E.; Fijałkowskia, K.; Grobelaka, A.; Grossera, A.; Worwaga, M.; Rorata, A.; Brattebob, H.; Almåsc, A.; Singhc, B.R. Sewage sludge disposal strategies for sustainable development. Environ. Res. 2017, 156, 36-42. [CrossRef]

29. Ministry of Environmental Protection. A National Survey of Soil Pollution Bulletin; Ministry of Environmental Protection: Beijing, China, 2014.

30. Sterritt, R.M.; Lester, J.N. Concentrations of heavy metals in forty sewage sludges in England. Water Air. Soil. Poll. 1980, 1, 125-131. [CrossRef]

31. Ou Yang, X.H.; Cui, J.; Tong, Q. Effects of long-term application of sewage sludge on soils and crops in agriculture. Agro-Environ. Prot. 1994, 13, 271-274.

32. Li, Y.X.; Wang, M.J.; Wang, J.S. Heavy metals in contemporary Chinese sewage sludges. Toxicol. Environ. Chem. 1999, 1-2, 229-240. [CrossRef]

33. Li, J.J. The Effect of Weathered Coal Activated by Ultrasonic on the Forms of Mercury in Soil and Soil Enzyme Activity; Shandong Agriculture University: Shandong, China, 2014.

34. Zhang, X.X.; Zha, T.G.; Guo, X.P.; Meng, G.X.; Zhou, J.X. Spatial distribution of metal pollution of soils of Chinese provincial capital cities. Sci. Total Environ. 2018, 643, 1502-1513. [CrossRef]

35. Steyn, C.E.; Herselman, J.E. Trace element concentrations in soils under different land uses in Mpumalanga province, South Africa, South African. J. Plant Soil. 2006, 4, 230-236.

36. Contina, M.; Goib, D.; Nobility, M. Land application of aerobic sewage sludge does not impair methane oxidation rates of soils. Sci. Total Environ. 2012, 20, 10-18. [CrossRef] [PubMed]

37. Ministry of Housing and Urban and Rural Construction in People's Republic of China. Disposal of Sludge from Municipal Wastewater Treatment Plants-Quality of Sludge Used in Forestland (CJ/T 362-2011); Ministry of Housing and Urban and Rural Construction in People's Republic of China: Beijing, China, 2011.

38. Mcgrath, S.P.; Chang, A.C.; Pang, A.L.; Witter, E. Land application of sewage sludge: Scientific perspectives of heavy metal loading limits in Europe and the United States. Environ. Rev. 1994, 2, 108-118. [CrossRef]

39. Ministry of Housing and Urban and Rural Construction in People's Republic of China. Statistical Yearbook on Urban Construction; Ministry of Housing and Urban-Rural Construction of the People's Republic of China: Beijing, China, 2017. 
40. Cheng, J.M. Study on Soil-Environmental Capacity in Main Soil-Types of Shandong Province; Shandong Normal University: Shandong, China, 2009.

41. Yi, S.Z. Application of soil environment background values in calculation of soil capacity. Shanghai Environ. Sci. 1992, 4, 34-36.

42. Yu, G.J.; Cheng, J.M.; Wang, Z.X.; Mu, J.B.; Jing, L.X. Soil-Environmental capacity in different vegetative types in Shandong province. Chin. J. Soil Sci. 2009, 2, 367-368.

43. Ministry of Ecological Environment Protection of People's Republic of China. Environmental Quality Standard for Soils Environmental Quality Standard for Soils (GB 15618-2018); Ministry of Housing and Urban-Rural Construction of the People's Republic of China: Beijing, China, 2018.

44. Environmental Engineering Assessment Center of State Environmental Protection Administration. Technical Methods of Environmental Impact Assessment; Environmental Science Press: Beijing, China, 2007.

45. Ministry of Housing and Urban and Rural Construction in People's Republic of China. Disposal of Sludge from Municipal Wastewater Treatment Plant-Quality of Sludge used in Garden or Park (GB23486-2009); Ministry of Housing and Urban-Rural Construction of the People's Republic of China: Beijing, China, 2009.

46. Oberg, G.; Mason-Renton, S.A. On the limitation of evidence-based policy: Regulatory narratives and land application of biosolids/sewage sludge in BC, Canada and Sweden. Environ. Sci. Policy 2018, 84, 88-96. [CrossRef]

47. Kang, J.; Zheng, Z.Q. Status and prosper of sludge composting for urban greening. Energ. Conserve. Environ. Prot. 2007, 7, 33-34.

48. Si, L.Q.; Chen, L.M.; Zheng, J.M.; Zhou, J.X.; Peng, X.W. Effects of mixed sewage sludge and garden waste composts on potting soil amendment. Pratacultural Sci. 2018, 1, 1-9.

49. Wang, X.; Chen, T.; Jia, Y.F.; Ge, Y.H. Studies on land application of sewage sludge and its limiting factors. J. Hazard. Mater. 2008, 2, 554-558. [CrossRef]

50. Duan, H.P.; Huang, J.M.; Cheng, W.Y. Application of sludge and garbage compost in highway slope greening. Highway 2008, 6, 204-207.

(C) 2020 by the authors. Licensee MDPI, Basel, Switzerland. This article is an open access article distributed under the terms and conditions of the Creative Commons Attribution (CC BY) license (http://creativecommons.org/licenses/by/4.0/). 